\title{
Demographic profile of CSOM in a rural tertiary care hospital
}

\author{
Bijan Basak ${ }^{1}$, Ganesh Chandra Gayen ${ }^{2}$, Munmun Das (Sarkar) ${ }^{3}$, Gautam Dhar ${ }^{4}$, \\ Ritam Ray ${ }^{5}$, Atanu Kumar Das ${ }^{6}$ \\ ${ }^{I}$ Assistant professor, Dept. of ENT, Burdwan Medical College \& Hospital, P.O. - Rajbati, Burdwan - 713104, \\ West Bengal, India \\ ${ }^{2}$ Assistant professor, Dept. of ENT, Burdwan Medical College \& Hospital, P.O. - Rajbati, Burdwan - 713104, \\ West Bengal, India \\ ${ }^{3}$ Assistant professor, Department of Microbiology, Assistant secretary of Medical Education, Dept. of Health \& \\ Family welfare, Govt of West Bengal, Swasthya Bhawan, GN-29, Sector-5, Salt Lake City, Kolkata-700091, West \\ Bengal, India \\ ${ }^{4}$ Associate professor, Department of Community Medicine, Assistant director of Medical Education, Dept. of \\ Health \& Family welfare, Govt of West Bengal, Swasthya Bhawan, GN-29, Sector-5, Salt Lake City, Kolkata- \\ 700091, West Bengal, India \\ ${ }^{5}$ RMO-cum-clinical tutor, Dept. of ENT, Burdwan Medical College \& Hospital,P.O. - Rajbati, Burdwan- \\ 713104, West Bengal, India \\ ${ }^{6}$ Postgraduate student, Dept. of ENT, Burdwan Medical College \& Hospital, \\ P.O. - Rajbati, Burdwan - 713104, West Bengal, India \\ Corresponding Author: Dr Ritam Ray
}

ABSTRACT:Objectives : To analyze the demographic and clinical aspects of chronic suppurative otitis media (CSOM) Materials and Methods : Prospective observational study over a period of 6 years (January, 2007 to December, 2013), 1717 patients with CSOM have been cared for in the department of ENT, Burdwan Medical College \& Hospital, Burdwan.

Results : CSOM commonly occurs in the age group from 11 to 30 years (40.50\%). Female predominate male. Tubotympanic type $(86.02 \%)$ is more common. Complications were associated with atticoantral type of CSOM.

Conclusion : CSOM is a common public health problem that is often wrongly trivialized by people. Health awareness campaign, improved health education and easy accessibility to health care facilities can reduce the morbidity and mortality of this disease and therefore can reduce the incidence of this disease.

KEY WORDS: CSOM ; Tubotympanic type ; atticoantral type ; Intracranial complication ; Extracranial complication

\section{INTRODUCTION}

CSOM is a major health problem in developing countries like India despite the advances in healthcare facilities. It is one of the common diseases in ENT practice. In our country burden of the disease is too high considering the huge population. CSOM is more common in low socio-economic status groups, communities with overcrowding, inadequate housing, poor hygiene, lack of breast feeding, poor nutrition, impaired immunologic status, passive smoking, frequent upper respiratory tract infection, high rates of nasopharyngeal colonization with potentially pathogenic bacteria and inadequate or unavailable health care. CSOM usually presents with otorrhoea, hearing loss, otalgia etc. causing psychological trauma and financial burden to the society.

\section{MATERIALS AND METHODS}

This retrospective analysis was done in the department of ENT , Burdwan Medical College, Burdwan, a tertiary care hospital in rural West Bengal. This study was carried out during the period from January, 2007 to december, 2013. All patients with CSOM who were admitted in our department of ENT , Burdwan Medical College \& Hospital, Burdwan, West Bengal during the above mentioned period were included in our study. A total no of 1717 patients were involved in this study. A detailed history was taken followed by meticulous clinical examination was done to evaluate the patient after admission. Data received from this study was evaluated carefully to assess the trend of presentation of CSOM. 


\section{OBSERVATION}

In our study, out of 1717 patients, 811 patients (47.23\%) were male and 906 patients (52.77\%) were female [Table-1]. Maximum patients fall within the age group between 11-30 years and among them the most common age group of presentation was $2^{\text {nd }}$ decade -671 patients $(39.08 \%)$ [Table -2]. We found that the tubotympanic type (86.02\%) is more common than atticoantral type (13.98\%). tubotympanic type is more common in female and atticoantral type is more common in male. 106 patients presented with complications and all of the patients had atticoantral type of CSOM. Complications are commonly found in male $(7.77 \%)$ patients than female patients $(4.74 \%)$ [Table -3$]$. Out of them, 70 patients had post aural abscess, 30 patients had intracranial complications, 6 patients presented with facial palsy and 1 patient presented with labyrinthitis [Table -4]. In the study period, it is seen that the trend of intracranial complication in gradually decreasing in nature and extracranial complication is increasing in nature, though there is no significant change in overall incidence of complicated otitis media.

\section{DISCUSSION}

Chronic suppurative otitis media (CSOM) is a disease associated with the structural change in middle ear and permanent abnormality of pars tensa or parse flaccida mostly as a sequelae of long standing middle ear effusion, inadequately treated acute otitis media or eustachian tube dysfunction and negative middle ear pressure. It is one of the common diseases in our day to day otorhinolaryngology practice. CSOM is more common in developing countries [1] than in developed ones. In the developing countries, poverty, ignorance, dearth of specialists and limited access to medical care amongst others conspire to worsen the course and complications of CSOM [2]. In a study conducted by Arunabha et al, $60 \%$ of their patients were from low socioeconomic class [3]. Poor living conditions, poor access to medical care, inadequate medical treatment, recurrent upper respiratory tract infections and nasal diseases have been recognized as risk factors for CSOM [4]. Overcrowding, poor hygiene and nutrition and poor living conditions have been suggested as a basis for the widespread prevalence of CSOM in developing countries [5,6,7]. In our study, female patients are more in number than male patients with a male female ratio of 1:1.2. Maximum number of the patients presented in a age group between 11 to 30 years. This suggest that CSOM tends to occur more in early decades of life and to leads to permanent defect in tympanic membrane with hearing loss.

CSOM is usually classified into two main types- atticoantral disease and tubotympanic disease [6,7]. Tubotympanic disease is characterized by a perforation in the parse tensa, are generally called safe from developing complications [6,7]. Atticoantral disease most commonly involve the pars flaccida and also posterior superior quadrant of pars tensa and is characterized by the formation of a retraction pocket in which keratin and dissquamated epithelial debris accumulates to produces cholesteatoma and considered to a dangerous form of the disease because of development of many intracranial and extracranial complications $[6,7,8]$. In the present study of 1717 cases, 1477 (86.02\%) cases were of tubotympanic type of CSOM and 240 (13.98\%) were of atticoantral type of CSOM. This data is comparable with previous studies $[6,8,9,10]$. It is also seen that tubotympanic type of CSOM is more common in both sexes. Compared to female, atticoantral type of CSOM is more commonly found in male patients in this study.

The atticoantral variety is more commonly associated with complications compared to the tubotympanic variety. Cholesteatoma with or without granulation tissue is the common causative factor for the development of complication in the patient of this type of CSOM [1,5,10,11]. Cholesteatoma causes erosion of bone and causes damage to the important structures around the around the middle ear cleft which leads to various extracranial complications like moastoiditis, postaural abscess, facial nerve paralysis, labyrinthitis and petrositis with bone destruction and intracranial complications like extradural abscess, subdural abscess, meningitis, encephalitis, brain abscess, lateral sinus thrombosis and otitic hydrocephalus [10]. In our study, we found $44.17 \%$ of patients with atticoantral type of CSOM presented with various types of complications and out of them, male patients are most commonly associated with complications than female. Postaural abscess $(65.1 \%)$ is the commonest complication in our study followed by intracranial complications (28.3\%), facial palsy $(5.66 \%)$ and labyrinthitis $(0.94 \%)$. In our hospital, there is no neurosurgical setup and therefore all patients with intracranial complications were referred to the higher centres for further and better management immediately after diagnosis. 


\section{TABLES}

Table - 1

Sex distribution in various types of CSOM

\begin{tabular}{|l|l|l|l|}
\hline & \multicolumn{1}{|c|}{ Tubotympanic type (\%) } & Atticoantral type (\%) & Total \\
\hline Female & $802(88.52)$ & $104(11.48 \%)$ & 906 \\
\hline male & $675(83.23 \%)$ & $136(16.77 \%)$ & 811 \\
\hline Total & 1477 & 240 & 1717 \\
\hline
\end{tabular}

Table - 2

Age distribution

\begin{tabular}{|l|l|l|}
\hline Age group & No. of patients & Percentage (\%) \\
\hline $0-10$ & 147 & $8.56 \%$ \\
\hline $11-20$ & 671 & $39.08 \%$ \\
\hline $21-30$ & 500 & $29.12 \%$ \\
\hline $31-40$ & 248 & $14.44 \%$ \\
\hline $41-50$ & 107 & $6.23 \%$ \\
\hline $51-60$ & 37 & $2.15 \%$ \\
\hline $61-70$ & 4 & $0.23 \%$ \\
\hline $71-80$ & 1 & $0.05 \%$ \\
\hline $81-90$ & 0 & $0 \%$ \\
\hline $91-100$ & 2 & $0.12 \%$ \\
\hline
\end{tabular}

Table -3

Sex distribution in complicated and uncomplicated CSOM

\begin{tabular}{|l|l|l|l|}
\hline & Complicated CSOM (\%) & $\begin{array}{c}\text { Uncomplicated CSOM } \\
(\%)\end{array}$ & Total \\
\hline Female & $43(4.74 \%)$ & $863(95.26 \%)$ & 906 \\
\hline male & $63(7.77 \%)$ & $748(92.23 \%)$ & 811 \\
\hline Total & 106 & 1611 & 1717 \\
\hline
\end{tabular}


Table -4

Distributions of complications of CSOM

\begin{tabular}{|l|l|l|l|l|l|}
\hline Year & $\begin{array}{c}\text { Facial } \\
\text { palsy }\end{array}$ & \multicolumn{1}{c|}{$\begin{array}{c}\text { Intracranial } \\
\text { Complication }\end{array}$} & $\begin{array}{c}\text { Post aural } \\
\text { abscess }\end{array}$ & Labyrinthitis & Total \\
\hline 2007 & 1 & 9 & 7 & 0 & 17 \\
\hline 2008 & 0 & 9 & 6 & 0 & 15 \\
\hline 2009 & 1 & 6 & 12 & 1 & 20 \\
\hline 2010 & 2 & 2 & 8 & 0 & 12 \\
\hline 2011 & 1 & 4 & 13 & 0 & 18 \\
\hline 2012 & 1 & 0 & 10 & 0 & 11 \\
\hline 2013 & 0 & 0 & 13 & 0 & 13 \\
\hline Total & $6(5.66 \%)$ & $30(28.30 \%)$ & $69(65.10 \%)$ & $1(0.94 \%)$ & 106 \\
\hline
\end{tabular}

\section{CONCLUSION}

Prevalence of CSOM is still high in rural area of our country and commonly found in younger age group. Early diagnosis of atticoantral type of CSOM and its appropriate management can reduce the incidence of complications. Health awareness campaign, improved health education and easy accessibility to health care facilities can reduce the morbidity and mortality of this disease and therefore can reduce the incidence of this disease.

\section{REFERENCE}

[1]. Vikram BK, Khaja N, Udayashankar SG et al. Clinico-epidemiological study of complicated and uncomplicated chronic suppurative otitis media. The Journal of Laryngology \& Otology 2008; 122:442-226.

[2]. Ibekwe TS, Nwaorgu OG. Classification and management challenges of otitis media in a resource-poor country. Niger J Clin Pract. 2011;14:262-9.

[3]. 3.Sengupta Arunbha, Anwar Tarique, Ghosh Debasish, Basak Bijan. A study of surgical management of chronic suppurative otitis media with cholesteatoma and its outcome. Indian J Otolaryngol Head Neck Surg. 2010;62(2):171-

76. DOI:10.1007/s12070-010-0043-3.

[4]. Adhikari P, Sinha BK, Pokharel NR, Aryal R, Ma J. Prevalence of chronic suppurative otitis media in school children of Kathmandu district. Journal of Institute of Medicine. 2007;29:310-12.s.

[5]. Akinpelu OV, Amusa YB, Komolafe EO et al. Challenges in management of chronic suppurative otitis media in a developing country. The Journal of Laryngology \& Otology 2008;122:16-20.

[6]. Chowdhury MA, Alauddin A.Comparative study between tubotympanic and atticoantral type of chronic suppurative otitis media.Bangladesh Med Res Counc Bull 2002;28(1): 36-44.

[7]. Mills RP. Scott-Brown's Otolaryngology:6th ed. Oxford: Butterworth-Heinemann:,Management of chronic suppurative otitis media. 1997. Chapter 10

[8]. Amin ASA, Joarder MAH, Farid N et al.A study on complication of chronic suppuration otitis media. Northern Medical Journal 1996; 5(1):1-4.

[9]. Hossain MM, Kundu SC, Haque MR et al. Extracranial complication of chronic otitis media. Mymensingh Med J 2006;15(1): 49.

[10]. Panda MK, Sreedharan S, Mann SBS et al. Prognostic factors in complicated and uncomplicated chronic otitis media.American Journal of Otolaryngology 1996;17(6): 391-196.

[11]. Grewal DS, Hathiram BT, Dwivedi A et al. Labyrinthine fistula: a complication of chronic suppurative otitis media. The Journal of Laryngology \& Otology 2003;117: 353-357. 